\title{
SHORT-TERM EFFECTS OF FERTILIZATION ON PHOTOSYNTHETIC ACTIVITY IN A DECIDUOUS TREE PLANTATION
}

\author{
*Guna Petaja, Ilze Karklina, Santa Neimane \\ Latvian State Forest Research Institute 'Silava', Latvia \\ *Corresponding author’s email: guna.petaja@silava.lv
}

\begin{abstract}
Fertilization is a method to enhance tree growth and timber production. Ammonium nitrate and wood ash are commonly used fertilizers, which can be applied at the same time to increase levels of both nitrogen and other macro- and micronutrients. We studied how ammonium nitrate and wood ash fertilization affects photosynthetic activity and transpiration at leaf level in a deciduous tree plantation in former agricultural land with mineral soil, located in the central part of Latvia (Keipene parish). Additionally, we performed foliar and soil nutrient analyses. Our results support the notion that nitrogen fertilization may not result in increased photosynthetic activity. It is possible that the photosynthetic activity has increased at canopy scale along with increasing leaf area, not at leaf scale. Wood ash addition seems to have resulted in higher photosynthetic activity for hybrid alder, although it could not be explained with phosphorus availability. Although closely related to photosynthesis, in most cases transpiration was not positively affected by fertilization. Environmental factors, such as humidity, temperature and wind speed may have a greater effect on this process.
\end{abstract}

Key words: wood ash, ammonium nitrate, photosynthetic activity, transpiration, foliar nutrient levels, plantation forestry.

\section{Introduction}

Fertilization is a silvicultural practice, applied to enhance tree growth and thus to increase timber production. In forests on mineral soils, nitrogen $(\mathrm{N})$ containing fertilizers are usually applied, whereas in peatland forests phosphorus $(\mathrm{P})$ and potassium $(\mathrm{K})$ fertilizers are mostly used (Saarsalmi \& Mälkönen, 2001). In forests on mineral soils the normally applied $\mathrm{N}$ dose with fertilizers is $150 \mathrm{~kg} \mathrm{ha}^{-1}$ and the following growth response is $20-25 \mathrm{~m}^{3} \mathrm{ha}^{-1}$ (Pukkala, 2017). The effect is the most intense in the first five years; however, it may last about 12 years (Saarsalmi \& Mälkönen, 2001). Ash is a by-product of biomass burning. It contains major bioavailable nutrients required for optimal tree growth: potassium $(\mathrm{K})$, phosphorus $(\mathrm{P})$, calcium $(\mathrm{Ca})$, magnesium $(\mathrm{Mg})$, and several trace elements; however, it does not contain nitrogen. Wood ash can also be used as liming material due to its high content of calcium oxide and hydroxide (Karltun et al., 2008). The recommended dose of $\mathrm{P}$ for peatland forests is $40-50 \mathrm{~kg} \mathrm{ha}^{-1}$, and that for $\mathrm{K}$ is $40-80 \mathrm{~kg}$ $\mathrm{ha}^{-1}$, which correspond to a wood ash dose of 2000 $5000 \mathrm{~kg}$ d.w. (Sikström, Almqvist, \& Jansson, 2010). In Finland, wood ash has been extensively applied to conifer stands in drained peatland forests since 1935 In Sweden, wood ash is produced on a large scale as well and applied to acidified forest soils in the southern part of the country (Lundström et al., 2003). There have been studies of the impact of forest fertilization on tree growth in Latvia as well. Wood ash and potassium sulphate application significantly improved tree growth in Norway spruce stands on both drained mineral and peat soil. The effect increased continually in the following 4 years (Okmanis et al., 2016). The effect of wood ash has also been evaluated for Scots pine and Norway spruce seedlings. Ash application (5 to $10 \mathrm{t} \mathrm{ha}^{-1}$ ) to restoration site on drained fertile peat soil one year before planting the seedlings resulted in an improved tree height and diameter growth. The effect was long-term and lasted 10 years after the seedlings had been planted (Jansone et al., 2020).

The worldwide plantation area is still expanding and most of them are fertilized at some stage of development. In addition to increased wood biomass, another benefit of fertilizer application is a shortened rotation period (Smethurst, 2010). Silver birch is the most frequently planted tree species in Latvia, followed by Norway spruce and black alder. In an experimental Norway spruce plantation in Kalsnava, Latvia, fertilization with ammonium nitrate $\left(\mathrm{NH}_{4} \mathrm{NO}_{3}\right)$, superphosphate and potassium nitrate with doses $56 \mathrm{~kg} \mathrm{ha}^{-1}$ of N, $24 \mathrm{~kg} \mathrm{ha}^{-1}$ of P and $44 \mathrm{~kg} \mathrm{ha}^{-1}$ of $\mathrm{K}$, respectively, significantly increased the dimensions of trees (ca. 17\% increase of stemwood volume, 7\% of diameter and 3\% - of height) in long-term (Jansons et al., 2016).

Photosynthesis can be defined as the process by which plants use sunlight to synthesize organic compounds from carbon dioxide and water. Transpiration is a process coupled with photosynthesis, and it is the discharge of water vapour through stomata (Tuzet, 2011). The two main functions of transpiration are reducing the temperature of the plant and providing the flow of water and nutrients to leaves. Photosynthetic response of plants to elevated concentrations of nutrients is complex and depend on many environmental and physiological factors. Studies show that tree canopy-scale photosynthesis increases either along with increasing needle $\mathrm{N}$ contents or additional leaf area, or both of these factors 
(Evans, 1989). In an N-deficient environment, the use of organic $\mathrm{C}$ compounds for $\mathrm{N}$ assimilation and growth is restricted and less carbohydrate is exported from plant leaves (Paul \&Driscoll, 1997).

The effect of $\mathrm{N}$ addition on photosynthesis at leafand canopy-scale depends on the balance between tree photosynthetic capacity and leaf area. Several studies suggest that high foliar $\mathrm{N}$ concentrations could lead to unbalanced nutrient availabilities. Phosphorus may play an important role in restricting leaf-scale photosynthetic capacity (Bauer et al., 2004; Ellsworth et al., 2015; Niinemets et al., 2001; Walker et al., 2014). Increased nitrogen availability and foliar concentrations do not always indicate increased photosynthetic activity. Under certain conditions nitrogen is increasingly allocated to nonphotosynthetic compounds, e.g., free amino acids (Näsholm \& Ericsson, 1990; Näsholm, 1994). The amino acid arginine is excessively found in needles of conifers growing in N-rich environment (Bauer et al., 2004; Nordin, Uggla, \& Näsholm, 2001). Arginine synthesis is often enhanced by low availability of $\mathrm{P}$ and several other macro- and micronutrients and could be a possible general response to environmental stress (Näsholm \& Ericsson, 1990). However, most of these studies focused on the fertilization effects on conifers and needle chemistry.

Variations in photosynthetic activity have been reported as determinants of plant productivity.
Studying this parameter can provide useful information on the growth potential of certain tree species and certain genotypes (Kundu et al., 1998; Orlović et al., 2014). The aim of the study was to investigate how forest fertilization influences leaf-level photosynthetic activity, transpiration and foliar nutrient levels in a deciduous tree plantation.

\section{Materials and Methods}

Study site - the Keipene plantation - is located in the central part of Latvia, Ogre municipality, Keipene parish $\left(56^{\circ} 55^{\prime} 59.3^{\prime} \mathrm{N} 25^{\circ} 08^{\prime} 15.4^{\prime} \mathrm{E}\right)$. Tree seedlings were planted in 2012 and 2013 on former agricultural land with mineral soil. In 2016, prior to fertilization, soil and leaf/needle analyses were carried out and phosphorous deficiency was diagnosed. Fertilizers were spread manually in 2017. In total, 16 parcels were fertilized with $0.44 \mathrm{t} \mathrm{ha}^{-1}$ ammonium nitrate and in parcels, where decreased tree growth was observed, wood ash was added $\left(3 \mathrm{t} \mathrm{ha}^{-1}\right)$. Wood ash was obtained from SIA Graanul Pellets pellet factory. The element concentration of wood ash was $9.6 \mathrm{~g} \mathrm{~kg}^{-1} \mathrm{P}, 25.96 \mathrm{~g} \mathrm{~kg}^{-1} \mathrm{~K} ., 153.32 \mathrm{~g} \mathrm{~kg}^{-1} \mathrm{Ca}$ and $11.58 \mathrm{~g} \mathrm{~kg}^{-1} \mathrm{Mg}$. The following tree species were included in the study: silver birch (Betula pendula Roth.), common alder (Alnus glutinosa (L.) Gaertn.), wild cherry (Cerasus avium (L.), Moench syn. Prunus avium L.) and also an aspen hybrid and an alder hybrid.

Table 1

Fertilizer use per plot and characteristics of fast-growing tree plantation in Keipene

\begin{tabular}{|c|c|c|c|c|}
\hline No. of plot & Tree species & Fertilized area, ha & Ammonium nitrate, kg & Wood ash, kg \\
\hline 18 & Black alder & 0.12 & 53 & - \\
\hline 20 & Silver birch & 0.12 & 53 & - \\
\hline $19 \mathrm{~b}$ & Hybrid alder & 0.06 & 26 & $\begin{array}{l}180(1.73 \mathrm{~kg} \mathrm{P}, 4.67 \mathrm{~kg} \mathrm{~K}, \\
27.60 \mathrm{~kg} \mathrm{Ca}, 2.10 \mathrm{~kg} \mathrm{Mg})\end{array}$ \\
\hline $6 \mathrm{~b}$ & Hybrid aspen & 0.09 & 40 & - \\
\hline 7 & Silver birch & 0.18 & 79 & - \\
\hline 22 & Black alder & 0.12 & 53 & - \\
\hline $8 \mathrm{a}$ & Wild cherry & 0.09 & 40 & $\begin{array}{c}270(2.59 \mathrm{~kg} \mathrm{P}, 7 \mathrm{~kg} \mathrm{~K}, \\
41.40 \mathrm{~kg} \mathrm{Ca}, 3.13 \mathrm{~kg} \mathrm{Mg})\end{array}$ \\
\hline $8 b$ & Hybrid aspen & 0.09 & 40 & - \\
\hline 24 & Black alder & 0.14 & 62 & - \\
\hline 25 & Silver birch & 0.14 & 62 & - \\
\hline $26 \mathrm{a}$ & Black alder & 0.08 & 35 & - \\
\hline $26 \mathrm{~b}$ & Hybrid alder & 0.04 & 18 & - \\
\hline $27 \mathrm{c}$ & Silver birch & 0.08 & 35 & - \\
\hline $27 \mathrm{~b}$ & Black alder & 0.08 & 35 & - \\
\hline 67 & Hybrid aspen & 0.12 & 53 & - \\
\hline 57 & Silver birch & 0.12 & 53 & - \\
\hline 57 & Silver birch & 0.12 & 53 & - \\
\hline
\end{tabular}




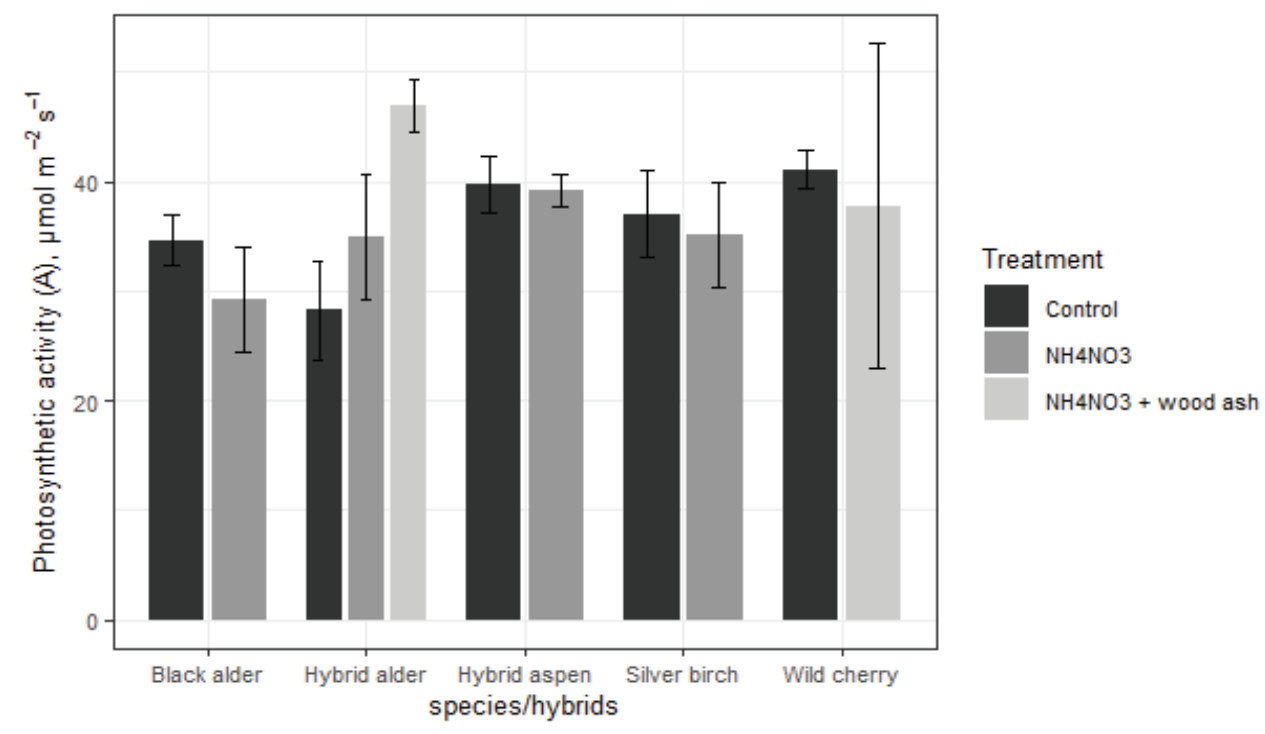

Figure 1. Photosynthetic activity (A) of fast-growing deciduous tree species and hybrids at different fertilization regimens (mean values $\pm \mathrm{SEM}$ ).

Photosynthetic activity (A) and transpiration (E) were measured with LCI Compact Portable Photosynthesis System, using the chamber for broadleaves. The photosynthetically active light intensity of leaf area (Qleaf) was set to $1500 \mu \mathrm{mol} \mathrm{m}^{-2}$ $\mathrm{s}^{-1}$. Measurements were carried out for 3 trees in each parcel. The samples of leaves ( 3 of each tree) were collected from the upper parts of tree canopies after taking measurements of photosynthetic activity. Soil samples were collected prior to foliar measurements in 2019, from depths of $0-10 \mathrm{~cm}, 10-20 \mathrm{~cm}, 20-40$ $\mathrm{cm}$ and $40-80 \mathrm{~cm}$.

The collected leaves were dried at $70{ }^{\circ} \mathrm{C}$ and milled. Leaves were not washed prior to preparation. Soil samples were air-dried, homogenized and sieved ( $2 \mathrm{~mm}$ pore size), according to the ISO 11465:1993. To measure macronutrient levels $-\mathrm{N}\left(\mathrm{g} \mathrm{kg}^{-1}\right), \mathrm{Ca}(\mathrm{g}$ $\left.\mathrm{kg}^{-1}\right), \mathrm{Mg}\left(\mathrm{g} \mathrm{kg}^{-1}\right), \mathrm{K}\left(\mathrm{g} \mathrm{kg}^{-1}\right)$ and $\mathrm{P}\left(\mathrm{g} \mathrm{kg}^{-1}\right)$, both soil and leaf samples were microwave-digested (Mars 6 iWave. CEM), using $65 \% \mathrm{HNO}_{3}$. Leaf extracts were analyzed with Inductively coupled plasma - optical emission spectrometer (ICP-OES, iCAP 7200 Duo Thermo Fisher Scientific) and soil extracts - with Flame Atomic Absorption Spectroscopy (FAAS, AAnalyst 200. Perkin Elmer).

Data were processed and analyzed with Microsoft Excel and Rstudio. We performed Student's T-test and Wilcoxon rank sum test with continuity correction (the test was chosen, depending on normality of data distribution) to estimate differences between the control and treatment plots at species level. Spearman rank correlation analysis was performed for foliar and soil nutrient concentrations. Statistical analyses were conducted, using software RStudio, at a 95\% confidence level.

\section{Results and Discussion}

In the control plots, where hybrid alder was planted, the average value of photosynthetic activity (A) was $28.3 \pm 4.5 \mu \mathrm{mol} \mathrm{m}^{-2} \mathrm{~s}^{-1}$, whereas in parcel, where ammonium nitrate was spread, the value was $34.9 \pm 5.7 \mu \mathrm{mol} \mathrm{m}^{-2} \mathrm{~s}^{-1}$, and in parcel, where wood ash was applied additionally to ammonium nitrate, the average value was $46.9 \pm 2.4 \mu \mathrm{mol} \mathrm{m}^{-2} \mathrm{~s}^{-1}$. The average values of photosynthetic activity for silver birch and hybrid aspen in both control and parcels treated with $\mathrm{NH}_{4} \mathrm{NO}_{3}$ did not differ significantly. For silver birch the average values were $37.1 \pm 3.9 \mu \mathrm{mol} \mathrm{m}^{-2} \mathrm{~s}^{-1}$ and $35.2 \pm 4.8 \mu \mathrm{mol} \mathrm{m}^{-2} \mathrm{~s}^{-1}$ in control and treatment parcels, accordingly, and for aspen hybrids the values were $39.8 \pm 2.5 \mu \mathrm{mol} \mathrm{m}^{-2} \mathrm{~s}^{-1}$ and $39.2 \pm 1.5 \mu \mathrm{mol} \mathrm{m}^{-2} \mathrm{~s}^{-1}$. For black alder and wild cherry higher photosynthetic activity was recorded in control plots $\left(34.7 \pm 2.3 \mu \mathrm{mol} \mathrm{m}^{-2} \mathrm{~s}^{-1}\right.$ un $29.3 \pm 4.8 \mu \mathrm{mol} \mathrm{m}^{-2} \mathrm{~s}^{-1}$ for black alder, $41.1 \pm 1.7 \mu \mathrm{mol} \mathrm{m} \mathrm{m}^{-2} \mathrm{~s}^{-1}$ and $37.8 \pm 14.8 \mu \mathrm{mol} \mathrm{m}^{-2} \mathrm{~s}^{-1}$ for wild cherry, respectively). Statistically significant increase in photosynthetic activity was found only in case of alder hybrid, when wood ash was applied along with ammonium nitrate $(p=0.0228$, Student's T-test). It is known that for silver birch the maximum photosynthetic efficiency at full sunlight is about $10-50 \%$ (Perala \& Alm, 1990). The comparison of the mean values of $A$ and the calculated standard error of the mean (SEM) are shown in Figure 1.

Silver birch is able to compensate the damage of leaves and defoliation by increasing photosynthetic activity. This means that even less optimal growing conditions would not affect photosynthesis and could explain the insignificant differences between control and $\mathrm{N}$ treatment plots. (OECD, 2006). 


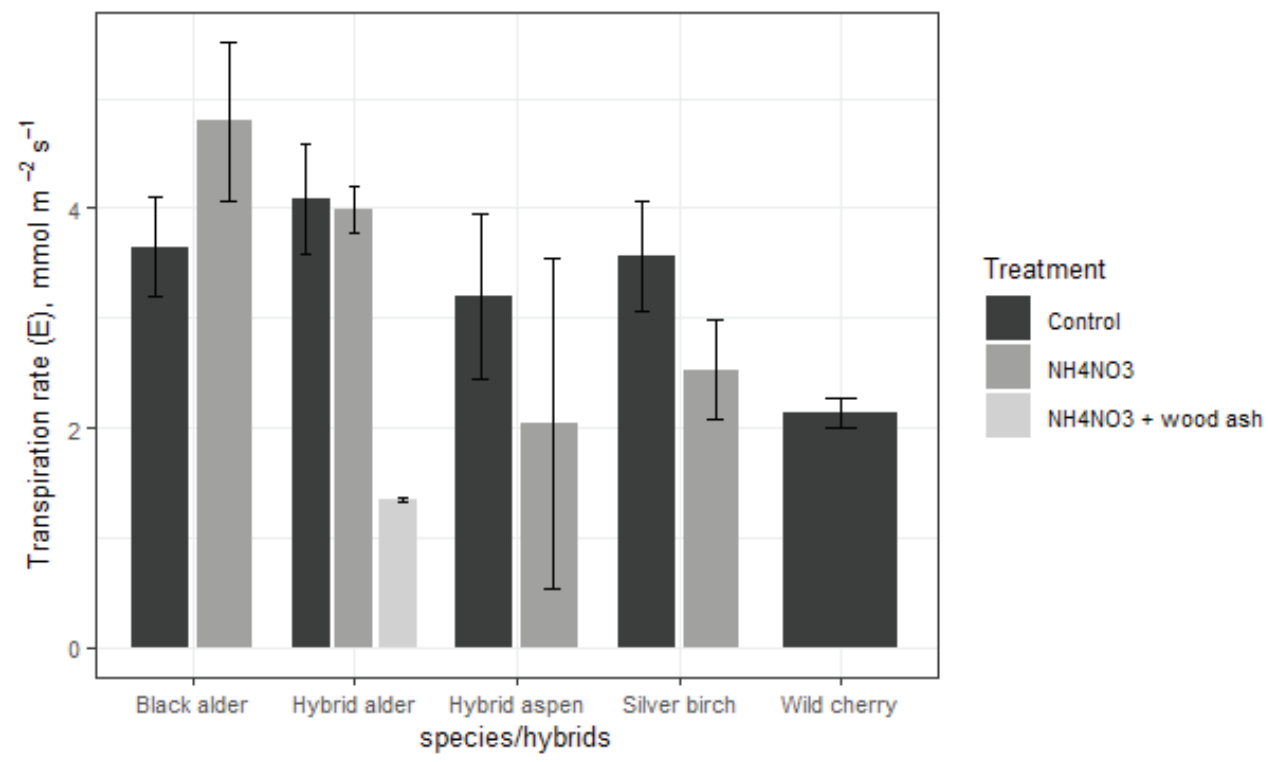

Figure 2. Transpiration (E) of fast-growing deciduous tree species and hybrids at different fertilization regimens (mean values \pm SEM).

Hybrid alder shows higher photosynthetic rate in the $\mathrm{N}$ treatment plots, compared with black alder. The rate is even higher, when wood ash is applied. Previous studies show that hybrids express higher photosynthetic rates, which is interpreted as being a result of a heterosis effect, resulting from an enhanced expression of genes coding for $\mathrm{CO}_{2}$ fixation-related proteins (Pärnik et al., 2014; Song et al., 2010).

Comparing the transpiration (E) measurements, higher values were only registered for black alder $\left(3.65 \pm 0.45\right.$ in control plots and $4.57 \pm 0.72 \mathrm{~mol} \mathrm{~m}^{-2} \mathrm{~s}^{-1}$ in treatment plots). In the rest of the cases in plots, where fertilizers have been applied, the measured values were lower (for birch $3.56 \pm 0.50 \mathrm{~mol} \mathrm{~m}^{-2} \mathrm{~s}^{-1}$ in control and $2.56 \pm 0.46 \mathrm{~mol} \mathrm{~m}^{-2} \mathrm{~s}^{-1}$ in treatment plots, for hybrid alder the transpiration values were $4.09 \pm 0.50,3.99 \pm 0.22$ and $1.35 \pm 0.02 \mathrm{~mol} \mathrm{~m}^{-2} \mathrm{~s}^{-1}$ in control, nitrogen treatment and wood ash/nitrogen treatment, respectively. For wild cherry, transpiration was registered only in control plots $(2.14 \pm 0.14 \mathrm{~mol}$ $\left.\mathrm{m}^{-2} \mathrm{~s}^{-1}\right)$. The comparison of the mean values of $\mathrm{E}$ and the calculated SEMs are shown in Figure 2. No general pattern was observed between fertilizer application and transpiration. Such factors as humidity, temperature and wind speed may have affected transpiration rates. Birches use water inefficiently and excessive

Table 2

Foliar nutrient content of fast-growing deciduous tree species and hybrids (mean values $\pm \mathrm{SEM}$ )

\begin{tabular}{|c|c|c|c|c|c|c|}
\hline Species & $\begin{array}{c}\text { Fertilization } \\
\text { regimen }\end{array}$ & $\mathbf{N}, \mathbf{g ~ k g}^{-1}$ & $\mathrm{P}, \mathrm{g} \mathrm{kg}^{-1}$ & $\mathrm{Ca}, \mathrm{g} \mathrm{kg}^{-1}$ & $\mathbf{M g}, \mathbf{g ~ k g}^{-1}$ & $\mathbf{K}, \mathbf{g ~ k g}^{-1}$ \\
\hline \multirow[t]{2}{*}{ Black alder } & Control & $38.0 \pm 0.8$ & $3.81 \pm 0.67$ & $11.68 \pm 1.07$ & $3.86 \pm 0.19$ & $14.37 \pm 0.65$ \\
\hline & $\mathrm{NH}_{4} \mathrm{NO}_{3}$ & $38.12 \pm 1.00$ & $3.67 \pm 0.17$ & $9.97 \pm 0.45$ & $3.59 \pm 0.15$ & $13.40 \pm 0.29$ \\
\hline \multirow[t]{2}{*}{ Silver birch } & Control & $39.47 \pm 0.90$ & $3.87 \pm 0.29$ & $7.09 \pm 1.07$ & $3.23 \pm 0.21$ & $10.21 \pm 0.70$ \\
\hline & $\mathrm{NH}_{4} \mathrm{NO}_{3}$ & $37.42 \pm 0.70$ & $3.79 \pm 0.11$ & $7.37 \pm 0.79$ & $3.44 \pm 0.13$ & $10.08 \pm 0.61$ \\
\hline \multirow[t]{3}{*}{ Hybrid alder } & Control & $37.50 \pm 0.46$ & $3.598 \pm 0.12$ & $9.95 \pm 0.79$ & $2.71 \pm 0.28$ & $13.35 \pm 0.65$ \\
\hline & $\mathrm{NH}_{4} \mathrm{NO}_{3}$ & $39.71 \pm 1.38$ & $4.050 \pm 0.20$ & $10.38 \pm 1.03$ & $3.19 \pm 0.23$ & $13.98 \pm 0.60$ \\
\hline & $\begin{array}{l}\mathrm{NH}_{4} \mathrm{NO}_{3}+ \\
\text { wood ash }\end{array}$ & $35.77 \pm 1.59$ & $2.97 \pm 0.09$ & $9.89 \pm 0.25$ & $3.28 \pm 0.23$ & $13.62 \pm 0.75$ \\
\hline \multirow[t]{2}{*}{ Hybrid aspen } & Control & $36.46 \pm 1.64$ & $4.84 \pm 0.28$ & $13.92 \pm 2.16$ & $3.97 \pm 0.11$ & $19.51 \pm 0.99$ \\
\hline & $\mathrm{NH}_{4} \mathrm{NO}_{3}$ & $36.66 \pm 1.24$ & $4.56 \pm 0.22$ & $10.91 \pm 1.01$ & $3.57 \pm 0.13$ & $17.58 \pm 0.47$ \\
\hline \multirow[t]{2}{*}{ Wild cherry } & Control & $34.50 \pm 2.14$ & $4.36 \pm 0.28$ & $14.47 \pm 1.76$ & $4.69 \pm 0.19$ & $16.29 \pm 1.11$ \\
\hline & $\begin{array}{l}\mathrm{NH}_{4} \mathrm{NO}_{3}+ \\
\text { wood ash }\end{array}$ & $37.56 \pm 0.72$ & $4.58 \pm 0.65$ & $19.95 \pm 1.85$ & $4.76 \pm 0.14$ & $18.22 \pm 1.60$ \\
\hline
\end{tabular}


transpiration is characteristic to this species. In large trees daily transpiration is about $514 \mathrm{~kg}$ water per $1 \mathrm{~kg}$ foliage (OECD, 2006). Black alder is another waterdemanding species, and their leaves lack a mechanism for transpiration control (Laessens, Oosterbaan, \& Peter, 2010). Results show that birch, black alder and alder hybrids have the highest transpiration rates.

Although no statistically significant differences in foliar chemistry between control and fertilized plots were found when comparing the treatments, an increase in phosphorus concentration was observed for hybrid alder in case of ammonium nitrate addition. It was expected that wood ash application would avert phosphorus deficiency, resulting in higher photosynthetic activity; however, the contrary was observed for hybrid alder - in plots treated with wood ash, phosphorus concentration was the lowest among treatments. One of the possible explanations for increasing photosynthetic activity could be the role of trace elements in photosynthesis, whose levels might have increased after addition of wood ash. An overall increase in foliar nutrient content was observed for wild cherry; however, it did not result in photosynthetic activity increase. Foliar nutrient levels are summarized in Table 2.

No statistically significant correlations were found between leaf nitrogen, leaf carbon and soil parameters (total soil carbon, total soil nitrogen and $\mathrm{pH}$ ); however, the correlations in most cases were weakly to moderately positive. The increased soil nitrogen content is reflected in increased foliar nitrogen levels, indicating that nitrogen in soil exists in forms available to plants.

\section{Conclusions}

1. The study indicates that nitrogen addition may not result in increased photosynthetic activity. It is also possible that the photosynthetic activity has increased at canopy scale, not at leaf scale. Wood ash addition seems to have resulted in higher photosynthetic activity for hybrid alder, although it could not be explained with phosphorus availability. Levels of other nutrients may have increased after wood ash application.

2. Although the process is closely related to photosynthesis, no impact of fertilization on transpiration was observed. Environmental factors, such as humidity, temperature and wind speed may play a larger role in this process.

\section{Acknowledgements}

European Development Fund Project 'Development of greenhouse gas emission factors and decision support tools for management of peatlands after peat extraction', agreement No. 1.1.1.1/19/A/064.

\section{References}

Bauer, G.A., Bazzaz, F.A., Minocha, R., Long, S., Magill, A., Aber, J., \& Berntson, G.M. (2004). Effects of chronic $\mathrm{N}$ additions on tissue chemistry, photosynthetic capacity, and carbon sequestration potential of a red pine (Pinus resinosa Ait.) stand in the NE United States. Forest Ecolology and Management. 196(1), 173-186. DOI: 10.1016/j.foreco.2004.03.032.

Ellsworth, D.S., Crous, K.Y., Lambers, H., \& Cooke, J. (2015). Phosphorus recycling in photorespiration maintains high photosynthetic capacity in woody species. Plant, Cell \& Environment. 38(6), 1142-1156. DOI: 10.1111 pce.12468.

Evans, J.R. (1989). Photosynthesis and nitrogen relationships in leaves of C3 plants. Oecologia. 78, 9-19. DOI: 10.1007/BF00377192.

Jansone, B., Samariks, V., Okmanis, M., Klavina, D., \& Lazdina, D. (2020). Effect of high concentrations of wood ash on soil properties and development of young Norway spruce (Picea abies (L.) Karst) and Scots pine (Pinus sylvestris L.). Sustainability, 12, 9479. DOI: 10.3390/su12229479.

Jansons, Ā., Matisons, R., Krišāns, O., Džeriņa, B., \& Zeps, M. (2016). Effect of initial fertilization on 34-year increment and wood properties of Norway spruce in Latvia. Silva Fennica, 50 (1), id 1346, 8 p. DOI: $10.14214 /$ sf.1346.

Karltun, E., Saarsalmi, A., Ingerslev, M., Mandre, M., Andersson, S., Gaitnieks, T., Ozolinčius, R., \& Varnagiryte-Kabasinskiene, I. (2008). Wood Ash Recycling - Possibilities And Risks. In D. Röser, A. Asikainen, K. Raulund-Rasmussen, I.Stupak (Eds.), Sustainable Use of Forest Biomass for Energy (pp. 79-108). Dordrecht, Springer. DOI: 10.1007/978-1-4020-5054-1_4.

Kundu, S.K., Islam, Q.N., Emmanuel, C.J.S.K., \& Tigerstedt, P.M.A. (1998). Observations on genotype $\times$ environment interactions and stability in the international neem (Azadirachta indica A. Juss.) provenance trials in Bangladesh and India. Forest Genetics. 5(2): 85-96.

Laessens, H., Oosterbaan, S., \& Peter, R.J. (2010). A review of the characteristics of Black Alder (Alnus glutinosa (L.) Gaertn.) and their implications for silvicultural practices. Forestry. 83(2), 163-175. DOI: 10.1093/forestry/cpp038. 
Lundström, U.S., Bain, D.C., Taylor, A.F.S., \& van Hees, P.A.W. (2003). Effects of acidification and its mitigation with lime and wood ash on forest soil processes: a review. Water, Air, \& Soil Pollution: Focus. 3(4). 5-28. DOI: 10.1023/A:1024115111377.

Näsholm, T. (1994). Removal of nitrogen during needle senescence in Scots pine (Pinus sylvestris L.). Oecologia. 99(3-4), 290-296. DOI: 10.1007/BF00627741.

Näsholm, T., \& Ericsson, A. (1990). Seasonal changes in aminoacids, protein and total nitrogen in needles of fertilized Scots pine trees. Tree Physiology. 6(3), 267-281. DOI: 10.1093/treephys/6.3.267.

Niinemets, Ü., Ellsworth, D.S., Lukjanova, A., \& Tobias, M. (2001). Site fertility and the morphological and photosynthetic acclimation of Pinus sylvestris needles to light. Tree Physiology. 21 (1), 1231-1244. DOI: 10.1093/treephys/21. 17.1231.

Nordin, A., Uggla, C., \& Näsholm, T. (2001). Nitrogen forms in bark, wood and foliage of nitrogen-fertilized Pinus sylvestris. Tree Physiology. 21(1), 59-64. DOI: 10.1093/treephys/21.1.59.

OECD. (2006), 'Section 2 - European White Birch (BETULA PENDULA ROTH)', in Safety Assessment of Transgenic Organisms, Volume 2: OECD Consensus Documents, OECD Publishing, Paris. DOI: 10.1787/9789264095403-3-en.

Okmanis, M., Skranda, I., Lazdiņš, A., \& Lazdiņa, D. (2016). Impact of wood ash and potassium sulphate fertilization on growth of Norway spruce stand on organic soil. Reseach for Rural Development. Annual $22^{\text {nd }}$ International Scientific Conference Proceedings. Jelgava, Latvia, 2016. Jelgava, Latvia: University of Agriculture. pp. 62-68.

Orlović, S., Stojnic, S., Pilipovic, A., Pekec, S., Mataruga, M., Cvjetkovic, B., \& Miljković, D. (2014). Variation in leaf photosynthetic traits of wild cherry (prunus avium L.) families in a nursery trial. Sumarski List. 138(7-8), 381-386.

Pärnik, T., Ivanova, H., Keerberg, O., Vardja, R., \& Niinemets, Ü. (2014). Tree age-dependent changes in photosynthetic and respiratory $\mathrm{CO}_{2}$ exchange in leaves of micropropagated diploid, triploid and hybrid aspen. Tree physiology. 34(6), 585-594. DOI: 10.1093/treephys/tpu043.

Paul, M.J., \& Driscoll, S.P. (1997). Sugar repression of photosynthesis: the role of carbohydrates in signalling nitrogen deficiency through source: sink imbalance. Plant, Cell \& Environment. 20(1), 110-116. DOI: 10.1046/j.1365-3040.1997.d01-17.x.

Perala, D.A., \& Alm, A.A. (1990). Reproductive ecology of birch: a review. Forest Ecology and Management. 32(1), 1-38. DOI: 10.1016/0378-1127(90)90104-J.

Pitman, R.M. (2006). Wood Ash Use in Forestry - a Review of the Environmental Impacts. Forestry: An International Journal of Forest Research. 79(5), 563-588. DOI: 10.1093/forestry/cp1041 11.

Pukkala, T. (2017). Optimal Nitrogen Fertilization of Boreal Conifer Forest. Forest Ecosystems.4(1), 3. DOI: 10.1186/s40663-017-0090-2 12.

Saarsalmi, A., \& Mälkönen, E. (2001). Forest Fertilization Research in Finland: A Literature Review. Scandinavian Journal of Forest Research. 16(6), 514-535. DOI: 10.1080/02827580152699358.

Sikström, U., Almqvist, C., \& Jansson, G. (2010). Growth of Pinus sylvestris after application of wood ash or P and K fertilizer to a peatland in southern Sweden. Silva Fennica. 44(3), 411-425. DOI: 10.14214/sf.139.

Smethurst, P. (2010). Forest fertilization: Trends in knowledge and practice compared to agriculture. Plant and Soil. 335(1), 83-100. DOI: 10.1007/s11104-010-0316-3.

Song, G.-S., Zhai, H.-L., Peng, Y.-G., Zhang, L., Wei, G., Chen X-Y., Xiao,Y-G., Wang, L., Chen, Y-J., Wu, B., Chen, B., Zhang, Y., Chen, H., Feng, X-J., Gong, W-K., Liu, Y., Yin, Zhi-J, Wang, F., Liu, G-Z., Xu, H-L., Wei, X-L., Zhao, X-L., Ouwerkerk, P.B.F, Hankemeier, T., Reijmers, T., van der Heijden, R., Lu, C-M., Wang, M., van der Greef, J., \& Zhu, Z. (2010). Comparative transcriptional profiling and preliminary study on heterosis mechanism of super-hybrid rice. Molecular Plant.3(6), 1012-1025. DOI: 10.1093/mp/ssq046.

Tuzet, A.J. (2011). Stomatal Conductance, Photosynthesis, and Transpiration, Modeling. In: Gliński J., Horabik J., Lipiec J. (eds) Encyclopedia of Agrophysics. Encyclopedia of Earth Sciences Series. Springer, Dordrecht. DOI: 10.1007/978-90-481-3585-1_213.

Walker, A.P., Beckerman, A.P., Gu, L.H.., Kattge, J., Cernusak, L.A., Domingues, T.F., Scales, J.C., Wohlfahrt, G., Wullschleger, S.D., \& Woodward, F.I. (2014). The relationship of leaf photosynthetic traits - Vcmax and Jmax - to leaf nitrogen, leaf phosphorus, and specific leaf area: a meta-analysis and modeling study. Ecology and Evolution. 4(16), 3218-3235. DOI: 10.1002/ece3.117. 